\title{
KOMPARASI MODEL PEMBELAJARAN THINK PAIR SHARE (TPS) DENGAN MODEL SIKLUS BELAJAR 7E TERHADAP HASIL BELAJAR MATEMATIKA
}

\author{
Nur Asrawati ${ }^{1}$ \\ 1Pendidikan Matematika, STKIP YPUP Makassar \\ nurasrawatiypup@gmail.com
}

\begin{abstract}
ABSTRAK
Jenis penelitian ini adalah penelitian eksperimen. Penelitian ini bertujuan untuk mengetahui perbendingan hasil belajar matematika dengan model pembelajaran think pair share (TPS) dan model siklus belajar 7E. populasi dalam penelitian ini adalah seluruh siswa kelas X SMK Muhammadiyah Bulukumba yang berjumlah 127 orang. Sampel dalam penelitian ini terdiri dari kelas X Kep1 yang berjumlah 25 orang dan X Kep2 yang berjumlah 23 orang. Berdasarkan hasil analisis statistik deskriptif diperoleh skor rata-rata hasil belajar yang diajar dengan model pembelajaran think pair share (TPS) 77,87 dengan standar deviasi 10,897 yang berada pada kategori baik sedangkan skor rata-rata hasil belajar yang diajar dengan model siklus belajar 7E adalah 68,16 dengan standar deviasi 10,015 yang juga berada pada kategori baik. Hasil analisis statistik deskriptif dan inferensial menunjukkan bahwa hasil belajar matematika siswa kelas X SMK Muhammadiyah Bulukumba yang diajar melalui model pembelajaran think pair share (TPS) lebih tinggi dari hasil belajar matematika yang diajar dengan model siklus 7E.
\end{abstract}

Kata Kunci: Think Pair Share, Siklus Belajar 7E, Hasil Belajar

\begin{abstract}
This type of research is experimental research. This study aims to compare the learning outcomes of mathematics with the Think Pair Share (TPS) Learning Model and the 7E Learning Cycle Model. The population in this study were all students of class X SMK Muhammadiyah Bulukumba totaling 127 people. The sample in the study consisted of class X Kep1 which numbered 25 people, class $X$ Kep2 which amounted to 23 people. Based on the results of descriptive statistical analysis obtained the average score of learning outcomes taught by Think Pair Share (TPS) Learning Model is 77.87 with a standard deviation of 10.897 which is categorized good while the average score of learning outcomes taught with the 7E Learning Cycle Model is 68,16 with a standard deviation of 10,015 which is categorized good. The results of descriptive and inferential statistical analysis showed that the mathematics learning outcomes of class I students of SMK Muhammadiyah Bulukumba were taught through the Think Pair Share (TPS) learning model higher than the mathematics learning outcomes taught by the 7E learning cycle model.
\end{abstract}

Keywords: Think Pair Share, 7E learning cycle, learning outcomes. 


\section{A. PENDAHULUAN}

Matematika merupakan salah satu pengetahuan yang sangat penting yang harus dikuasai dengan baik oleh siswa. Matematika secara etimologi berarti ilmu yang diperoleh dengan bernalar. Dengan mempelajari matematika kita akan belajar bernalar secara kritis, kreatif dan aktif, cara berpikir matematika juga sistematis melalui urutan yang teratur. Disamping itu belajar matematika juga mengajarkan kita untuk menjadi lebih teliti, cermat dan tidak ceroboh dalam bertindak.

Salah satu masalah yang paling sering kita jumpai dalam proses pembelajaran matematika adalah mengenai pemilihan model pembelajaran yang digunakan oleh guru, khususnya di SMK Muhammadiyah Bulukumba. Siswa umumnya masih mengalami kesulitan dalam belajar matematika. Mereka menganggap matematika adalah pelajaran yang paling sulit karena harus menghafalkan rumus-rumus bahkan sebagian siswa menganggap bahwa matematika adalah pelajaran yang paling membosankan. Oleh karena itu, agar proses pembelajaran dapat berlangsung secara aktif perlu adanya pemilihan model pembelajaran yang tepat agar mereka perlahan dapat menyukai pelajaran matematika.

Berdasarkan observasi dengan guru mata pelajaran matematika kelas X SMK Muhammadiyah Bulukumba bahwa pembelajaran masih berfokus pada guru, karena kurangnya minat siswa terhadap mata pelajaran matematika mengakibatkan sehingga setiap semester sekitar 30 sampai 45 percen siswa tidak memenuhi standar ketuntasan minimal (KKM) yaitu 75. Selain itu guru mata pelajaran matematika menginformasikan juga bahwa kemampuan siswa dalam menyelesaikan soal-soal berbentuk cerita sangat rendah, misalnya pada materi SPLDV dan Program Linear, rumus-rumus mereka hafalkan sehingga ketika diberikan soal mereka langsung mampu menerapkan rumus tersebut, tanpa mengetahui konsep dasar matematika secara mendalam, sehingga ketika diberikan soal yang sedikit berbeda dari contoh yang diberikan, mereka sudah kesulitan untuk menjawabnya, sehingga berdampak pada rendahnya daya serap siswa terhadap mata pelajaran matematika. Kesulitan selanjutnya menurut guru yang mengajar adalah siswa sangat kesulitan menyelesaikan soal-soal dalam bentuk soal cerita, Hal ini menandakan bahwa level kognitif siswa SMK Muhammadiyah Bulukumba masih dalam level pemahaman (C2), yang semestinya untuk tingkatan sekolah menengah atas, mereka minimal sudah berada pada level kognitif Analisis, sehingga pada akhirnya mereka lulus sekolah hanya pintar teori tetapi miskin aplikasi.

Berdasarkan permasalahan yang ada di atas, salah satu solusi yang diatawarkan penulis adalah mencoba menggunakan model pembelajaran Think Pair Share (TPS) dan siklus belajar 7E. Menurut Lie (2008: 58), keunggulan Think Pair Share (TPS) adalah: (1) meningkatkan kemandirian siswa; (2) meningkatkan partisipasi siswa untuk menyumbangkan pemikiran karena leluasa dalam mengungkapkan pendapatnya; dan (3) melatih kecepatan berpikir siswa. model pembelajaran think pair share (TPS) Menyediakan waktu berpikir dan meningkatkan kualitas respon siswa, siswa menjadi lebih aktif dalam berpikir mengenai konsep dalam mata pelajaran, siswa lebih memahami tentang konsep topik pelajaran selama diskusi, siswa dapat belajar dari siswa lain, setiap siswa dalam kelompoknya mempunyai kesempatan untuk berbagi atau menyampaikan idenya. Model pembelajaran ini melatih siswa untuk berani berpendapat dan menghargai pendapat dari teman yang lain. Dengan demikian, diharapkan siswa mampu bekerja sama, saling membutuhkan dan saling bergantung pada kelompok kecil secara kooperatif atau kelompok (Shoimin, 2017:208). Jika siswa terlibat aktif dalam proses belajar maka mereka akan belajar jauh lebih baik. Hal ini disebabkan dalam proses belajar tersebut 
siswa secara aktif berpikir tentang apa yang dipelajari dan kemudian bagaimana menerapkan apa yang telah dipelajari dalam situasi nyata

Model pembelajaran selanjutnya yang ditawarkan adalah model siklus belajar 7E. Model Siklus Belajar 7E (Elicit, Engage, Explore, Explain, Elaborate, Evaluate, Extend) merupakan Model pembelajaran yang dapat meningkatkan pemahaman siswa terhadap konsep-konsep maupun prinsip-prinsip ilmiah dari suatu materi pelajaran. Model siklus belajar 7E dikembangkan dari Model siklus belajar 5E. Sama halnya dengan Model siklus belajar 5E, peran guru dalam Model siklus belajar 7E adalah sebagai fasilitator dan mediator pembelajaran. Perbedaan antara Model siklus belajar 5E dan 7E adalah bahwa pada Model siklus belajar 7E diawali dengan pengungkapan pengetahuan awal (prior knowledge) siswa tentang suatu topikmateri pelajaran melalui pengajuan pertanyaan-pertanyaan oleh guru (elicit) dan diakhiri dengan pemberian kesempatan kepada siswa untuk mengembangkan dan menerapkan konsepkonsep maupun prinsip-prinsip ilmiah yang telah dikuasainya pada situasi yang lebih kompleks dalam kehidupan sehari-hari (extend) (Sadia, 2014:25).

Uraian singkat Model pembelajaran Think Pair Share (TPS) dan Model siklus belajar 7E (Learning Cycle 7E) secara singkat diuaraikan sebagai berikut :

\section{1) Think (berpikir)}

Pelaksanaan pembelajaran TPS diawali dari berpikir sendiri mengenai pemecahan suatu masalah. Tahap berpikir menuntut siswa untuk lebih tekun dalam belajar dan aktif mencari referensi agar lebih mudah dalam memecahkan masalah atau soal yang diberikan guru.

\section{2) Pair (berpasangan)}

Setelah diawali dengan berpikir, siswa kemudian diminta untuk mendiskusikan hasil pemikirannya secara berpasangan Tahap diskusi merupakan tahap menyatukan pendapat masing-masing siswa guna memperdalam pengetahuan mereka. Diskusi dapat mendorong siswa untuk aktif menyampaikan pendapat dan mendengarkan pendapat orang lain dalam kelompok serta mampu bekerja sama dengan orang lain.

\section{3) Share (berbagi)}

Setelah mendiskusikan hasil pemikirannya, pasangan-pasangan peserta didik yang ada diminta untuk berbagi hasil pemikiran yang telah dibicarakan bersama pasangannya masingmasing kepada seluruh kelas. Tahap berbagi menuntut siswa untuk mampu mengungkapkan pendapatnya secara bertanggung jawab, serta mampu mempertahankan pendapat yang telah disampaikannya. Kelebihan dan kekurangan model pembelajaran Think Pair Share (TPS) menurut Shoimin (2017:211)

1) Kelebihan model pembelajaran ThinkPairShare (TPS) adalah sebagai berikut:

a) TPS mudah diterapkan diberbagai jenjang pendidikan dan dalam setiap kesempatan.

b) Menyediakan waktu berpikir untuk meningkatkan kualitas respon siswa.

c) Siswa menjadi lebih aktif dalam berpikir mengenai konsep dalam mata pelajaran.

d) Siswa lebih memahami tentang konsep topik pelajaran selama diskusi.

e) Peserta didik dapat belajar dari siswa lain.

f) Setiap siswa dalam kelompoknya mempunyai kesempatan untuk berbagi atau menyampaikan idenya.

2) Kelemahan

a) Banyak kelompok yang melapor dan perlu dimonitor.

b) Lebih sedikit ide yang muncul.

c) Jika ada perselisihan, tidak ada penengah.

Menurut Lihar dkk (2016:774-775), langkah-langkah dari model siklus belajar 7E (Learning Cycle 7E) adalah sebagai berikut: 


\section{1) Kegiatan awal}

a) Guru mengucap salam dan mengecek kehadiran siswa

b) Guru menyampaikan tujuan dan metode pembelajaran kepada siswa

c) Guru menyampaikan bahwa akan ada penghargaan bagi siswa yang aktif saat pembelajaran berlangsung dan menghimbau agar selama kegiatan pembelajaran siswa berpartisipasi aktif.

d) Tahap Elicit,guru melakukan apersepsi dengan Tanya jawab mengenai materi yang berhubungan dengan materi yang dipelajari dan guru meminta siswa agar mengangkat tangan apabila hendak menjawab pertanyaan.

e) Tahap Engange, guru menjelaskan materi yang dibutuhkan siswa dan memberi motivasi pada siswa terhadap materi yang akan dipelajari.

\section{2) Kegiatan inti}

a) Guru membagi siswa menjadi beberapa kelompok, setiap kelompok terdiri dari 5-6 siswa.

b) Tahap Explore, guru membagikan LKS untuk masing-masing kelompok, dan meminta siswa mengamati materi di LKS, kemudian siswa membaca, mencermati, dan mencatat informasi yang diperoleh. Setelah itu guru meminta siswa membuat pertanyaan mengenai apa yang telah diamati sebelumnya pada LKS, kemudian menyelesaikan LKS yang telah dibagikan.

c) Tahap Explain, siswa berbagi pendapat atau ide dengan teman sekelompoknya, mendiskusikan penyelesaian yang terbaik berkaitan dengan masalah yang terdapat dalam LKS, dan membuat suatu kesimpulan berkaitan dengan pengetahuan yang telah diperoleh. Sedangkan guru memantau jalannya diskusi.

d) Tahap Elaborate, guru meminta siswa menyiapkan hasil dari diskusi dan perwakilan dari beberapa kelompok menyampaikan hasil diskusinya didepan kelas, kelompok lain yang tidak maju mendengarkan, mengajukan pertanyaan, berpendapat, ataupun berkomentar. Guru dapat bertanya dan memberikan komentar terhadap hasil diskusi kelompok dan memberikan saran.

e) Tahap Evaluate, guru memberikan kuis kepada siswa untuk dikerjakan secara individu.

f) Tahap Extend, guru memberikan penguatan tentang konsep yang sudah benar dan meluruskan jika ada konsep yang kurang tepat, dengan mengajak siswa untuk memberikan contoh permasalahan sehaari-hari.

Kelebihan model siklus belajar 7E (Learning Cycle 7E), (Sadia, 2014:27)

1) Guru dapat memilih strategi pembelajaran yang lebih efektif, berdasarkan hasil pengungkapan pengetahuan awal siswa (elicit).

2) Siswa mudah untuk mengingat kembali terhadap materi pelajaran yang telah mereka pelajari sebelumnya.

3) Melalui kegiatan persiapan (anggement), siswa akan menjadi lebih aktif dan rasa ingin tahunya tinggi.

4) Melalui kegiatan eksplorasi, siswa akan mengalami proses belajar penemuan (menemukan masalah), sehingga konsep-konsep yang dipelajari akan menjadi lebih bermakna dan tahan lama.

5) Kemampuan berpikir tingkat tinggi (berpikir kritis dan kreatif) siswa akan menjadi lebih aktif dalam proses pembelajaran.

6) Melalui kegiatan pada fase eksplanasi, siswa akan memiliki kemampuan untuk berkomunikasi yang lebih baik.

7) Melalui kegiatan pada fase pengembangan (extended), siswa akan menjadi sangat kuat dalam pemahaman dan pengembangan materi pelajaran

Berdasarkan tinjauan pustaka dan kerangka pikir yang dikembangkan dari rumusan masalah, maka hipotesis yang diuji dalam penelitian ini adalah "hasil belajar matematika siswa yang diajar 
dengan model pembelajaran Think Pair Share (TPS) lebih tinggi dari hasil belajar matematika siswa yang diajar dengan model siklus belajar 7E (Learning Cycle 7E)".

\section{B. METODE}

Untuk menjawab permasalahan di atas telah dilakukan penelitian kuasi eksperimen. Desain penelitian yang digunakan adalah desain randomized control group design dengan dua perlakuan yang berbeda, yaitu kelompok pertama sebagai kelompok eksperimen satu yang diajar dengan menggunakan model pembelajaran Think Pair Share dan kelompok kedua sebagai kelompok eksperimen dua yang diajar dengan model siklus belajar 7E. Populasi dalam penelitian ini adalah semua siswa kelas X SMK Muhammadiyah Bulukumba. Jumlah sampel penelitian tersebut yaitu 25 siswa pada kelas X Kep1 dan 23 siswa kelas X Kep2. Jumlah populasi tesebut 127 siswa, maka peneliti mengambil sebagian dari anggota populasi untuk dijadikan sampel penelitian. Selanjutnya kedua kelas tersebut diundi untuk menentukan kelompok eksperimen satu dan kelompok eksperimen dua, setelah itu kedua kelas tersebut diberikan preetest yntuk membuktikan bahwa kedua kelas tersebut memiliki siswa yang berada pada level kognitif yang sama.

Instrumen yang digunakan dalam penelitian ini adalah instrumen tes hasil belajar. Tes ini dimaksudkan untuk mengetahui dan membandingkan tingkat hasil belajar siswa terhadap materi yang diajar dengan model pembelajaran Think Pair Share (TPS) dan model siklus belajar 7E. tes hasil belajar terdiri dari 5 nomor soal dan berbentuk (essai) serta dikembangkan sendiri oleh peneliti berdasarkan kisi-kisi soal. Kisi-kisi instrumen (terlampir) biasanya dibuat dalam bentuk tabel yang berisi kompetensi dasar, materi pokok, indikator sebagai tolak ukur, nomor soal atau nomor butir (item) merupakan pertanyaan-pertanyaan yang telah dijabarkan dari indikator, bentuk soal dan bobot soal.

\section{HASIL DAN PEMBAHASAN}

Data tentang hasil belajar diperoleh dari tes yang dilaksanakan pada kelas eksperimen satu berjumlah 23 dan kelas eksperimen dua berjumlah 25. Data tes hasil belajar matematika siswa yang diajar dengan model pembelajaran Think Pair Share (TPS) mulai dari mean, median, modus, standar deviasi, varians, jangkauan, skor maksimum, skor minimum. Deskripsi data Skor Hasil Belajar Matematika yang diajar dengan Model Pembelajaran Think Pair Share.

Tabel 1. Deskripsi data Skor Hasil Belajar Matematika Model Pembelajaran Think Pair Share

\begin{tabular}{cc}
\hline Statistik & Nilai Statistik \\
\hline Ukuran Sampel & 23 \\
Skor Maksimum & 96 \\
Skor Minimum & 55 \\
Jangkauan & 41 \\
Skor Rata-rata & 77,92 \\
Varians & 100,307 \\
Standar deviasi & 10,897 \\
Median & 80,00 \\
Modus & 87 \\
\hline
\end{tabular}

Sumber: Data Diolah

Berdasarkan tabel 1, dari 23 siswa yang diberikan tes hasil belajar matematika pokok bahasan Program Linear diperoleh skor rata-rata hasil belajar matematika yang diajar dengan model pembelajaran Think Pair Share 77,87 yang menunjukan bahwa skor rata-rata hasil belajar matematika berpusat pada 77,87 dengan standar deviasi 10,897 artinya sebagian besar 
hasil belajar yang diperoleh siswa berada disekitar 67,33 - 88,70 dari nilai rata-ratanya. Skor yang dicapai siswa tersebar antara skor 55 yang merupakan skor minimum hingga skor 96 yang merupakan skor maksimum. Jangkauan 41 merupakan selisih antara skor maksimum dan skor minimum, median 80,00 berarti $50 \%$ dari jumlah siswa yang memperoleh skor di atas 80,00 dan $50 \%$ dari jumlah siswa yang memperoleh skor di bawah 79,50. Sedangkan modus 87 artinya dari 23 siswa dengan rentang skor hasil belajar 55 - 96, nilai yang paling banyak diperoleh siswa adalah 87 yaitu sebanyak 4 orang. Berdasarkan modus tersebut dapat disimpulkan bahwa tingkat kemampuan siswa cukup bervariasi.

Deskripsi data Skor Hasil Belajar Matematika yang diajar dengan Model pembelajaran Siklus Belajar 7E.

Tabel 2. Deskripsi Data Skor Hasil Belajar Matmatika Model pembelajaran Siklus Belajar 7E

\begin{tabular}{cc}
\hline Statistik & Nilai Statistik \\
\hline Ukuran Sampel & 25 \\
Skor Maksimum & 86 \\
Skor Minimum & 48 \\
Jangkauan & 38 \\
Skor Rata-rata & 68,16 \\
Varians & 100,307 \\
Standar deviasi & 10,015 \\
Median & 65 \\
Modus & 75 \\
\hline
\end{tabular}

Sumber: Data diolah

Berdasarkan tabel 2, dari 25 siswa yang diberikan tes hasil belajar matematika pokok bahasan Program Linear diperoleh skor rata-rata hasil belajar matematika yang diajar dengan model siklus belajar 7E 68,16 yang menunjukan bahwa skor rata-rata hasil belajar matematika berpusat pada 68,16 dengan standar deviasi 10,015 artinya nilai-nilai siswa cenderung berada disekitar nilai rata-rata yang berkisar antara 52,022 -76,421 dengan penyebaran data yang berada pada 52 sampai 76. Skor yang dicapai siswa tersebar antara skor 48 yang merupakan skor minimum hingga skor 86 yang merupakan skor maksimum. Jangkauan 38 merupakan selisih antara skor tertinggi dan skor terendah, sedangkan median 75 berarti 50\% dari jumlah siswa yang memperoleh skor di atas 75 dan 50\% jumlah siswa yang memperoleh skor di bawah 75, dan modus 75 berarti dari 25 siswa diperoleh hasil belajar dengan skor 48 - 86, nilai yang paling banyak diperoleh siswa adalah 75 sebanyak 5 orang. Berdasarkan modus tersebut dapat disimpulkan bahwa tingkat kemampuan siswa cukup bervariasi.

Untuk lebih jelasnya, perbandingan skor tes hasil belajar yang diajar dengan model pembelajaran Think Pair Share (TPS) dan model siklus belajar 7E pada pokok bahasan Program Linear, dapat didukung dengan melihat diagram batang sebagai berikut:

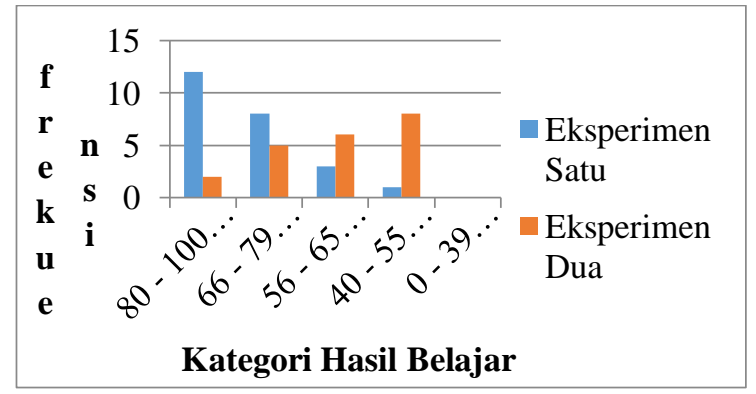

Gambar 1. Karegori Hasil Belajar 
Kategori hasil belajar matematika siswa kelas XI SMK Muhammadiyah Bulukumba berdasarkan frekuensi. Berdasarkan diagram batang pada gambar di atas, kategori baik sekali didominasi oleh kelas eksperimen satu, dikategori baik didominasi oleh kelas eksperimen satu, kategori cukup didominasi oleh kelas eksperimen dua, kategori kurang didominasi oleh kelas eksperimen dua, sedangkan untuk kategori gagal tidak ada siswa yang mendapat nilai yang berada pada kategori gagal.

Pada penelitian ini, dilaksanakan pengajaran kepada kedua kelompok yaitu kelompok eksperimen satu yang diajarkan dengan model pembelajaran Think Pair Share dan kelompok eksperimen dua diajar dengan model siklus belajar 7E. berdasarkan hasil perhitungan normalitas dan homogenitas dari hasil belajar matematika siswa pada pokok bahasan Program Linear, kedua kelompok mempunyai kemampuan yang hampir sama.

Dari hasil analisis statistik deskriptif diperoleh rata-rata skor hasil belajar materi Program Linear siswa yang diajar dengan model pembelajaran Think Pair Share adalah sebesar 77,87. Berdasarkan pengkategorian Arikunto, nilai rata-rata skor hasil belajar matematika tersebut dikategorikan baik, dan rata-rata hasil belajar siswa yang diajar dengan model siklus belajar 7E sebesar 68,16; berdasarkan kriteria pengkategorian yang digunakan nilai rata-rata skor hasil belajar tersebut berada pada kategori cukup.

Berdasarkan rumusan hipotesis penelitian yang digunakan yaitu H0: $\mu 1 \leq \mu 2$ melawan H1: $\mu 1$ $>\mu 2$ dikaitkan dengan hasil penelitian yang diuji dengan statistik inferensial, maka H0 ditolak dan $\mathrm{H} 1$ diterima. Ini berarti hasil belajar matematika siswa pada pokok bahasan Program Linear yang diajar dengan model pembelajaran Think Pair Share lebih tinggi dari rata-rata hasil belajar matematika siswa yang diajardengan model siklus belajar 7E. Hal ini disebabkan karena karena kedua model pembelajaran yang digunakan masing-masing memiliki kelebihan dan kekurangan. Kejadian di kelas membuktikan siswa pada kelas eksperimen dua yang diajar dengan menggunakan model pembelajaran siklus belajar 7E kurang aktif dalam kegiatan proses belajar mengajar. Hal ini terlihat kurangnya respon siswa pada saat guru melontarkan pertanyaan dan pada saat guru meminta siswa untuk mengajukan soal. Hal yang sama juga terjadi pada saat guru menyuruh siswa untuk menanyakan kembali hal-hal yang belum mengerti dari materi yang sudah disampaikan. Selain itu, pada saat diberikan soal latihan banyak siswa yang mengalami kesulitan untuk menyelesaikan soal-soal latihan tersebut meskipun sudah dijelaskan. Begitu pula dengan tugas umah yang diberikan, tidak semua siswa mengerjakan tugas dan yang mengerjakan tugas pun hasilnya kurang memuaskan. Akibatnya pada saat diberikan tes, nilainilai hasil belajarnya pun kurang memuaskan dengan skor rata-rata 68,16.

Lain halnya siswa pada kelas eksperimen satu yang diajar dengan menggunakan model pembelajaran Think Pair Share. Pada kelas ini siswa lebih antusias pada saat proses belajar mengajar berlangsung. Siswa lebih cepat memahami materi yang disampaikan.Banyak siswa yang sering bertanya maupun menjawab pertanyaan yang dilontarkan oleh guru. Selain itu kegiatan dalam kelompok juga berjalan dengan baik karena anggota kelompok saling membantu satu sama lain. Mereka saling berlomba-lomba menyelesaikan soal-soal yang diberikan oleh guru. Sehingga nilai hasil tesnya pun memuaskan dengan skor rata-rata 77,87. Hasil penelitian ini menunjukan bahwa hasil belajar matematika siswa kelas X SMK Muhammadiyah Bulukumba yang diajar dengan model pembelajaran Think Pair Share lebih tinggi dibandingkan dengan hasil belajar siswa yang diajar dengan model pembelajaran siklus belajar 7E.

Berdasarkan penelitian ini, maka dapat disimpulkan bahwa pembelajaran matematika dengan model pembelajaran Think Pair Share (TPS) mempengaruhi pencapaian kemampuan belajar siswa secara klasikal. Proses pembelajaran seperti ini menekankan 
keterlibatan siswa untuk aktif berinteraksi sehingga mereka dapat mengkonstruksi pengetahuannya sendiri.

Telah banyak penelitian tentang model pembelajaran Think Pair Share (TPS) dan Model siklus 7E telah dilakukan. Hasil penelitian Ibrahim (2010) menunjukkan bahwa penerapan model pembelajaran Think Pair and Share tebukti dapat meningkatkan hasil belajar mahasiswa. Hasil penelitian Jannah et al. (2013) menunjukkan bahwa target untuk aktivitas belajar siswa yaitu sebanyak $70 \%$ siswa aktif dalam pembelajaran. Persentase jumlah siswa yang aktif pada siklus II meningkat mencapai 70,3\%. Hasil penelitian Nugraha (2013) menunjukkan bahwa penggunaan metode pembelajaran TPS disertai media Index Card Match efektif meningkatkan prestasi belajar materi ikatan kimia siswa kelas X SMA Negeri 2 Karanganyar semester gasal tahun pelajaran 2012/2013. Hasil penelitian Wahyuni (2013) menunjukkan bahwa metode eksperimen dengan strategi TPS (Think-Pair-Share) dalam model pembelajaran diskusi berpengaruh positif terhadap hasil belajar siswa ranah kognitif pada materi perpindahan panas di kelas VII SMP Negeri 2 Buduran Sidoarjo, selanjutnya penelitian tentang model siklus 7E, hasil penelitian Opas, et al. (2009); Sornsakda, et al. (2009) yang melakukan penelitian eksperimen mengenai pengaruh model siklus belajar 7E terhadap prestasi belajar, keterampilan berpikir kritis, dan keterampilan proses sains. Hasil penelitiannya menunjukkan bahwa penerapan model siklus belajar 7E dapat meningkatkan prestasi belajar, keterampilan berpikir kritis, dan keterampilan proses sains siswa. Siribunnam dan Tayraukham (2009) melakukan penelitian eksperimen mengenai pengaruh model siklus belajar 7E terhadap keterampilan berpikir siswa, prestasi belajar, dan sikap siswa. Hasil penelitiannya menunjukkan bahwa penerapan model siklus belajar 7E dapat meningkatkan keterampilan berpikir siswa ke arah yang lebih baik, dapat meningkatkan prestasi belajar, dan sikap siswa dibandingkan dengan siswa yang belajar dengan model konvensional.

\section{PENUTUP}

\section{Kesimpulan}

Rata-rata hasil belajar matematika yang diajar dengan model pembelajaran Think Pair Share berada pada kategori baik yaitu 77,87 dengan standar deviasi 10,897, Rata-rata hasil belajar matematika yang diajar dengan model Siklus Belajar 7E juga berada pada kategori baik yaitu 68,16 dengan standar deviasi 10,015, sehingga dapat disimpulkan bahwa meskipun kedua model pembelajaran ini mempunyai rerata berada pada kategori baik tetapi Rata-rata hasil belajar matematika yang diajar dengan model pembelajaran Think Pair Share (TPS) lebih tinggi dari pada hasil belajar matematika yang diajar dengan model Siklus Belajar 7E pada siswa kelas X SMK Muhammadiyah Bulukumba.

\section{Saran}

Pembelajaran hendaknya melibatkan siswa secara aktif dalam proses pembelajaran supaya siswa tidak cepat bosan dan mampu meningkatkan rasa percaya diri siswa sehingga mereka mampu dan semangat dalam mengikuti pembelajaran dengan baik. Salah satu alternatif untuk meningkatkan partisipasi peserta didik tersebut adalah dengan menerapkan model pembelajaran Think Pair Share. Bagi para guru, pemahaman terhadap berbagai model pembelajaran sangat diperlukan. Dan salah satunya adalah model pembelajaran Think Pair Share. Model pembelajaran ini adalah suatu model pembelajaran kooperatif yang memberikan siswa waktu untuk berpikir dan merespon serta saling membantu satu sama lain. Model pembelajaran ini menggunakan metode diskusi berpasangan. Dengan model pembelajaran ini siswa dilatih bagaimana mengutarakan pendapat dan siswa juga belajar bagaimana menghargai pendapat orang lain dengan tetap mengacu pada materi atau tujuan pembelajaran. Kepada peneliti lain yang ingin melaksanakan penelitian, supaya benar-benar memahami konsep model pembelajaran ini 
sehingga dapat mempersiapkan instrument sebaik mungkin agar data yang diperoleh benarbenar menggambarkan kemampuan responden yang sebenarnya

\section{DAFTAR PUSTAKA}

Arikunto. (2012). Dasar-dasar Evaluasi Pendidikan. Jakarta: Bumi Aksara

Isjoni, H. (2012). Pembelajaran Kooperatif. Yogyakarta: Pustaka pelajar.

Jannah, Rikhinati, A. N. C. Saputro, \& S. Yamtinah. 2013. Penerapan Model Pembelajaran Think Pair Share (TPS) Disertai Buku Saku untuk Meningkatkan Aktivitas dan Prestasi Belajar Kimia pada Materi Minyak Bumi Kelas X SMA Negeri Gondangrejo Tahun Pelajaran 2012/2013. Jurnal Pendidikan Kimia (JPK), 2(4):19-23.

Jatmiko. (2015). Eksperimen Model Pembelajaran Think Pair Share. Jurnal ilmiah pendidikan matematika. vol. 3, No. 2. Diakses februari 2015.

Jihad dan Haris. (2008). Evaluasi pembelajaran. Jakarta

Kasmadi, Abdul Gani Haji, Yusrizal. 2016. Model Pembelajaran Learning Cycle 7E, (http://jurnal.unsyiah.ac.id/jpsi). Jurnal Pendidikan Sains Indonesi.Vol.04, $\quad$ No. 02.hlm.106-112.

Kurmiasih dan Sani.(2015). Ragam Pengembangan Model Pembelajaran. Kata Pena. Lestari dan Yudhanegara. (2017). Penelitian Pendidikan Matematika. Bandung: Refika Aditama

Lihar Raudina Izzati, Sutopo, Henny Ekana Chrisnawati. ModelLearning Cycle 7E, Prosiding Seminar Matematika dan Pendidikan Matematika. (http://jurnal.fkip.uns.ac.id)..Diakses November 2016.

Nugraha, D. A., E. Susanti VH, \& M. Masykuri. 2013. Efektivitas Metode Pembelajaran Kooperatif Think Pair Share (TPS) yang Dilengkapi Media Kartu Berpasangan (Index Card Match) Terhadap Prestasi Belajar Siswa Pada Materi Ikatan Kimia Kelas X Semester Gasal SMA 2 N Karanganyar Tahun Pelajaran 2012/2013. Jurnal Pendidikan Kimia (JPK), 2(4):174181.

Purwanto.(2016). Evaluasi hasil belajar. Yogyakarta: Pustaka Pelajar.

Sadia, W. (2014).Model-model pembelajaran Sains konstruktivistik. Yogyakarta: Graha Ilmu Sanjaya, W. (2010). Kurikulum dan Pembelajaran. Jakarta: Kencana Prenada Madia Group

Shoimin. A. (2017). 68 Model Pembelajaran Inofatif dalam Kurikulum 2013.Yogyakarta: Ar - Ruzz Media.

Siribunnam, \& Tayraukham. 2009. Effect of 7-E, KWL, and Conventional Instruction on Analytical Thingking, Learning Achievement and attitudes toward Chemistry Learning. Journal of Social Science 5 (4): 279-282

Sornsakda, S., Suksringarm, P. and Singseewo, A. (2009). Effects of Learning Environmental Education Using The 7E-Learning Cycle with Metacognitive Techniques and Teacher's Handbook Approaches on Learning Achievement, Integrated Science Process Skills and Critical Thinking of Mathayomsuksa 5 Students with Different Learning Achievement. Pakistan Journal of Social Sciences. 6(5): 297-303

Subana. (2011). Dasar-dasar penelitian ilmiah. Bandung: Pustaka Setia.

Sundayana. (2016). Media dan Alat Peraga dalam Pembelajaran Matematika. Bandung: Alfabeta

Wahyuni \& R. Hasanah. 2013. Pengaruh Penerapan Metode Eksperimen Dengan strategi TPS (Think Pair Share) dalam Model Pembelajaran Diskusi Terhadap Hasil belajar Siswa Pada Materi Perpindahan Panas Di Kelas VII SMP Negeri 2 Buduran Sidoarjo. Jurnal Inovasi Pendidikan Fisika, 2(3):89-94. 